LAWRENCE LIVERMORE NATIONAL LABORATORY
California GAMA Special Study: Ion exchange and trace element surface complexation reactions associated with applied recharge of low-TDS water in the San Joaquin Valley, California

Walt W. McNab Jr., Michael J. Singleton, Jean E. Moran, and Bradley K. Esser

Lawrence Livermore National Laboratory

August 17, 2010

Final report for the California State Water Resources Control Board

GAMA Special Studies Task 7.5 :

Water Quality and Redox Conditions - Effects of Irrigation and Groundwater Management 


\section{Disclaimer}

This document was prepared as an account of work sponsored by an agency of the United States government. Neither the United States government nor Lawrence Livermore National Security, LLC, nor any of their employees makes any warranty, expressed or implied, or assumes any legal liability or responsibility for the accuracy, completeness, or usefulness of any information, apparatus, product, or process disclosed, or represents that its use would not infringe privately owned rights. Reference herein to any specific commercial product, process, or service by trade name, trademark, manufacturer, or otherwise does not necessarily constitute or imply its endorsement, recommendation, or favoring by the United States government or Lawrence Livermore National Security, LLC. The views and opinions of authors expressed herein do not necessarily state or reflect those of the United States government or Lawrence Livermore National Security, LLC, and shall not be used for advertising or product endorsement purposes.

\section{Auspices Statement}

This work performed under the auspices of the U.S. Department of Energy by Lawrence Livermore National Laboratory under Contract DE-AC52-07NA27344. 


\section{California GAMA Special Study:}

Ion exchange and trace element surface complexation reactions associated with applied recharge of low-TDS water in the San Joaquin Valley, California

Walt W. McNab Jr., Michael J. Singleton, Jean E. Moran, and Bradley K. Esser

\section{Lawrence Livermore National Laboratory}

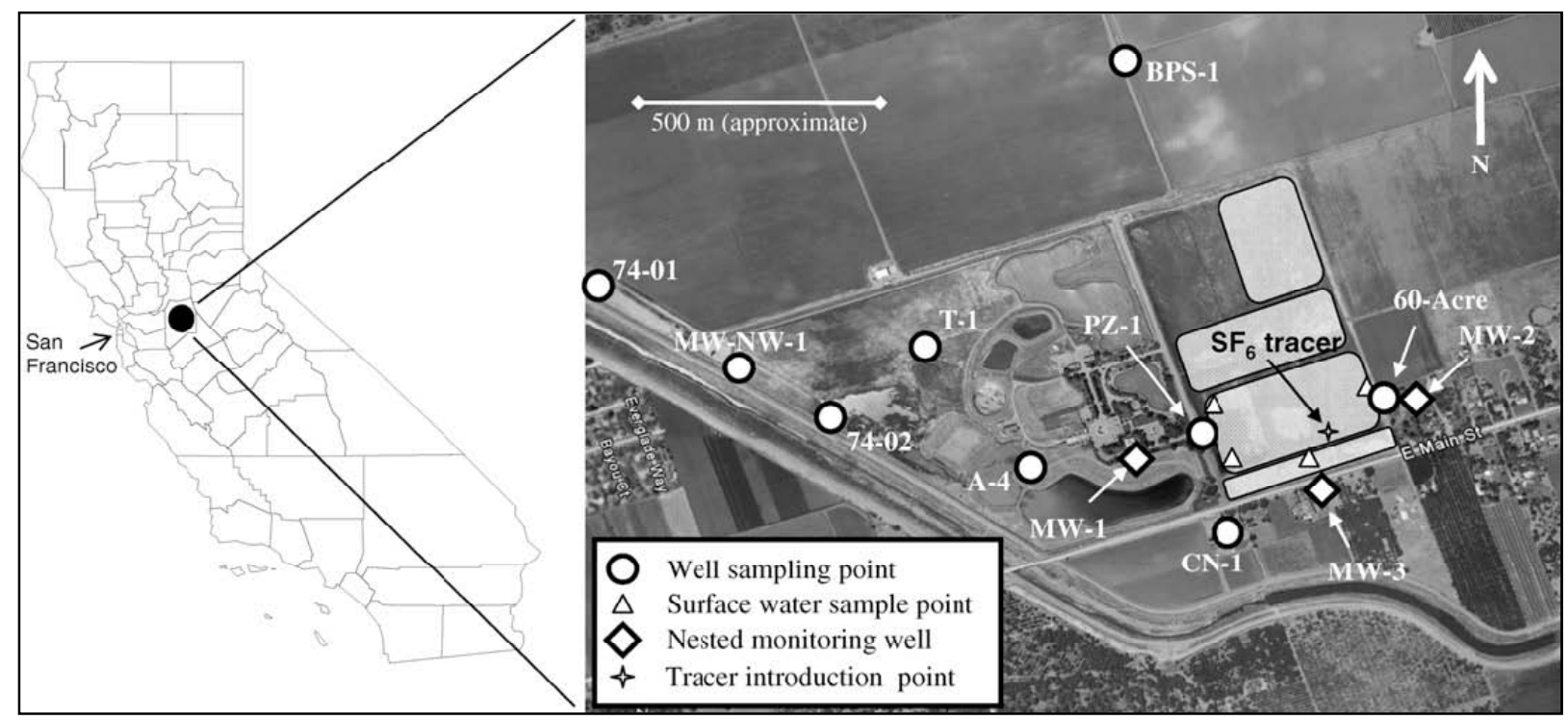

Final Report for GAMA Special Studies Task 7.5

LLNL-TR-450392

Prepared in cooperation with the California

State Water Resource Control Board 


\section{Suggested citation:}

McNab Jr W. W., Singleton M. J., Moran J. E., and Esser B. K. (2010) GAMA Special Study: Ion exchange and trace element surface complexation reactions associated with applied recharge of low-TDS water in the San Joaquin Valley, California. Lawrence Livermore National Laboratory LLNL-TR-450392, 15 pages. 


\title{
California GAMA Special Study: Ion exchange and trace element surface complexation reactions associated with applied recharge of low-TDS water in the San Joaquin Valley, California
}

\author{
Walt W. McNab Jr., Michael J. Singleton, Jean E. Moran, and Bradley K. Esser \\ Lawrence Livermore National Laboratory \\ Prepared in cooperation with the California State Water Resource Control Board
}

\section{Executive Summary}

Under the Special Studies portion of the State Water Resources Control Board's Groundwater Ambient Monitoring and Assessment (GAMA) program, water quality topics of statewide relevance are addressed through focused research studies carried out in collaboration with Lawrence Livermore National Laboratory. The study described here addresses changes in groundwater quality associated with managed aquifer recharge of high quality water.

Managed aquifer recharge, including the storage of potable water in accessible aquifers as an alternative to surface reservoir storage, is a valuable water resource management tool for water purveyors. Managed recharge usually entails the infiltration of water that is out of chemical equilibrium with local aquifer minerals, potentially resulting in mineral reactions, redox reactions, and trace element mobilization that can affect water quality and local aquifer permeability. Improvements to recharge water quality (e.g., remineralization of organic material, removal of organic compounds, denitrification) have been observed with recharge of agricultural return water and wastewater. In contrast, water quality changes associated with managed recharge of high quality surface water, e.g. Sierra Nevada runoff containing very low total dissolved solids (TDS), have received less attention.

The objective of this study was to understand the geochemical interactions of high quality, imported recharge water with underlying aquifer materials associated with a four-year-old managed aquifer recharge project underway near Stockton, California, U.S.A. in California's San Joaquin Valley. The study employed advanced analytical methods to delineate mixing of ambient groundwater and recharge water in the subsurface, including both an introduced dissolved gas tracer and groundwater age dating $\left({ }^{3} \mathrm{H} /{ }^{3} \mathrm{He}\right.$ method). This information, used in concert with extensive major ion, trace element, and isotopic data, allowed development of a geochemical model that provides a framework for interpreting the geochemical response of the local groundwater system to recharge of imported water.

The study site, operated by Stockton East Water District (SEWD), consists of ponds adjacent to agricultural fields and a surface water treatment plant. Approximately 7000 acre-ft of imported water from New Melones and New Hogan reservoirs are recharged annually. Wells adjacent to the pond had tracer detections 6 to 11 days after the peak tracer detection in the 
pond, while nested monitoring wells downgradient had detections after 17 days. Production wells screened below semi-confining units had no tracer detections and had groundwater ages indicating that produced water recharged at least several decades ago.

Overall groundwater quality in the area is very good, with $<17 \mathrm{mg} / \mathrm{L}$ nitrate $\left(\mathrm{as} \mathrm{NO}_{3}{ }^{-}\right)$, total organic carbon $<1 \mathrm{mg} / \mathrm{L}$, and a low frequency of detection of low level volatile organic compounds. Major element chemistry of recharged water is controlled by 1) mixing between low TDS recharge water and higher TDS ambient groundwater, and 2) water-rock reactions including carbonate dissolution and cation exchange on clay surfaces.

Arsenic concentrations that hover around the $\mathrm{MCL}$ of $10 \mu \mathrm{g} / \mathrm{L}$ are the most significant water quality issue at the SEWD site. The trace elements arsenic, vanadium, and molybdenum how a sharp increase in concentration in wells strongly affected by recent recharge of imported water. The increase is not consistent with simple mixing between recharge and ambient groundwater. Geochemical modeling shows that $\mathrm{pH}$-driven surface reactions on hydrous ferric oxides can produce the observed increases in oxyanion-forming trace elements such as arsenic. The modeling is consistent with the observed mobilization of arsenic by managed aquifer recharge and the with the observed differences in $\mathrm{pH}$ between ambient groundwater and recharging surface water.

In summary, the multiple independent indicators measured as part of this study comprise an internally consistent picture of imported recharge water mixing with ambient groundwater in various proportions in the shallow aquifer underlying and surrounding the recharge ponds. Direct natural indicators of the imported recharge water - groundwater age, TDS, $\delta^{18} \mathrm{O}, \delta^{13} \mathrm{C}-$ as well as an introduced tracer all appear to be generally correlated in groundwater samples collected at the site, reflecting the varying extent of artificial recharge water present in the shallow aquifer. In addition, the introduction of the high quality (i.e., low-TDS), artificial recharge water, being out of equilibrium with the aquifer material, results in the mobilization of oxyanionic trace elements (As, V, and Mo) as well as changes the proportion of exchangeable cations in solution.

These findings have important implications for the management of the managed aquifer recharge facility. If hydrous ferric oxides do control groundwater arsenic concentrations, then maintenance of oxic conditions in recharging water to avoid dissolution of these oxides is essential to prevent much higher degrees of arsenic mobilization than currently observed.

The main body of this report is an article published in Applied Geochemistry, a peer-reviewed journal.

McNab Jr W. W., Singleton M. J., Moran J. E., and Esser B. K. (2009) lon exchange and trace element surface complexation reactions associated with applied recharge of low-TDS water in the San Joaquin Valley, California. Applied Geochemistry 24(1), 129-137. 


\title{
Ion exchange and trace element surface complexation reactions associated with applied recharge of low-TDS water in the San Joaquin Valley, California
}

\author{
Walt W. McNab Jr. ${ }^{\mathrm{a}, *}$, Michael J. Singleton ${ }^{\mathrm{b}}$, Jean E. Moran ${ }^{\mathrm{c}}$, Bradley K. Esser ${ }^{\mathrm{b}}$ \\ ${ }^{a}$ Environmental Restoration Department, Lawrence Livermore National Laboratory, P.O. Box 808, L-530, Livermore, CA 94551, USA \\ ${ }^{\mathrm{b}}$ Chemical Biology and Nuclear Science Division, Lawrence Livermore National Laboratory, USA \\ ${ }^{\mathrm{c}}$ Department of Earth and Environmental Science, California State University, East Bay, Hayward, CA, USA
}

\section{A R T I C L E I N F O}

Article history:

Received 8 February 2008

Accepted 7 November 2008

Available online 19 November 2008

Editorial handling by P.B. McMahon

\begin{abstract}
A B S T R A C T
Stable isotope data, a dissolved gas tracer study, groundwater age dating, and geochemical modeling were used to identify and characterize the effects of introducing low-TDS recharge water in a shallow aerobic aquifer affected by a managed aquifer recharge project in California's San Joaquin Valley. The data all consistently point to a substantial degree of mixing of recharge water from surface ponds with ambient groundwater in a number of nearby wells screened at depths above $60 \mathrm{~m}$ below ground surface. Groundwater age data indicate that the wells near the recharge ponds sample recently recharged water, as delineated by stable $O$ and $C$ isotope data as well as total dissolved solids, in addition to much older groundwater in various mixing proportions. Where the recharge water signature is present, the specific geochemical interactions between the recharge water and the aquifer material appear to include ion exchange reactions (comparative enrichment of affected groundwater with $\mathrm{Na}$ and $\mathrm{K}$ at the expense of $\mathrm{Ca}$ and $\mathrm{Mg}$ ) and the desorption of oxyanion-forming trace elements (As, $\mathrm{V}$, and $\mathrm{Mo}$ ), possibly in response to the elevated $\mathrm{pH}$ of the recharge water.
\end{abstract}

(c) 2008 Elsevier Ltd. All rights reserved.

\section{Introduction}

Managed aquifer recharge, including the storage of potable water in accessible aquifers as an alternative to surface reservoir storage, is a valuable water resource management tool for water purveyors (Bouwer, 2002; Jones, 2003; Pyle, 1988). Nonetheless, managed recharge entails the introduction of a water composition that is often out of thermodynamic equilibrium with local aquifer mineral assemblages, potentially resulting in mineral precipitation/dissolution reactions, redox reactions, and trace element mobilization that can exert detrimental effects on water quality as well as local aquifer permeability. Improvements to recharge water quality (e.g., remineralization of organic material, sorption or biodegradation of organic compounds, denitrification) are oftentimes observed in situations involving agricultural return water and treated or untreated wastewater recharge. In contrast, geochemical processes associated with groundwater banking, which may entail recharge water characterized by very low total dissolved solids (TDS), have received less attention.

The simplest model for the quality of water recovered from a groundwater banking operation is the binary mixing concept: that groundwater quality at any location in the aquifer is solely a func-

\footnotetext{
* Corresponding author. Fax: +1925 4243155.

E-mail address: mcnabl@llnl.gov (W.W. McNab).
}

tion of the proportion of low-TDS recharge water mixed with ambient groundwater. This model is applicable to conservative species such as $\mathrm{Cl}^{-}$but is not accurate for sorbing species such as major cations, which are affected by ion exchange, or many trace elements, which form complexes with active sites on metal oxide surfaces naturally occurring in the aquifer material. For example, among the comparatively few published studies, Arthur et al. (2002) observed elevated concentrations of both As and $U$ from a managed recharge experiment conducted in a Florida limestone. Because both elements occurred at very low concentrations in the recharge water as well as the ambient groundwater compositions, the observed increases were assumed to reflect recharge water chemistry-induced mobilization (desorption).

The objective of this study was to understand the geochemical interactions of high quality, imported recharge water with underlying aquifer materials associated with a 4-a-old managed aquifer recharge project underway near Stockton, California, USA in California's San Joaquin Valley. The study employed advanced analytical methods to delineate mixing of ambient groundwater and recharge water in the subsurface, including both an introduced dissolved gas tracer and groundwater age dating $\left({ }^{3} \mathrm{H} /{ }^{3} \mathrm{He}\right.$ method). This information, used in concert with extensive major ion, trace element and isotopic data, allowed development of a geochemical model that provides a framework for interpreting the geochemical response of the local groundwater system to recharge of imported water. 


\section{Methods}

\subsection{Site background}

The Stockton East Water District (SEWD) Water Treatment Plant provides a majority of the drinking water supply to the city of Stockton, California (population 300,000), approximately $90 \mathrm{~km}$ east of the San Francisco Bay Area (Fig. 1). The facility receives water from the New Melones and New Hogan Reservoirs in the foothills of the Sierra Nevada some $50 \mathrm{~km}$ to the east. Beginning in 2003, the SEWD has been periodically discharging surplus water from these sources into surface impoundment ponds to facilitate groundwater recharge under the Farmington Recharge Program, a joint groundwater storage effort by SEWD, other local water purveyors, and the US Army Corps of Engineers (Green, 2008). The objectives of the recharge program include drought protection, addressing overdraft, and mitigating saltwater intrusion. The amount of recharge has varied over time but has generally averaged approximately $2.5 \times 10^{6} \mathrm{~m}^{3} / \mathrm{a}$. Treatment of water diverted to the recharge ponds has varied and has included, at times, passage through granular activated $\mathrm{C}$.

The site is essentially flat and is underlain to a depth of approximately $60 \mathrm{~m}$ by the Pleistocene-age Modesto and Riverbank Formations which are comprised of fluvial sedimentary materials (Burow et al., 2004; Marchand and Allwardt, 1981). Existing groundwater wells in the vicinity of the recharge ponds include nested monitoring wells as well as local agricultural supply wells (Fig. 1); well construction details indicate that most of these wells are screened across portions of the Modesto Formation. Exceptions include water supply wells 74-01 and 74-02 which are screened entirely in pre-Modesto sedimentary materials at depths below $60 \mathrm{~m}$. Past aquifer tests have indicated that these two wells are hydraulically isolated to some extent from wells screened at shallower depths (Montgomery Watson Harza, 2006).

\subsection{Analytical techniques}

Surface water and groundwater samples for multiple geochemical and isotopic analyses were collected as part of a baseline survey in August 2006. Subsequent monthly sampling rounds through mid-2007 entailed selected analytes in a subset of the groundwater wells. In all, samples were collected from wells PZ-1, A-4, 74-01, 74-02, 60-Acre, T-1, CN-1, BPS-1, CWS-35, MW-NW-1, and the MW-1, MW-2 and MW-3 well clusters, each of the latter screened at shallow (10-m depth), intermediate (15-m depth), and deeper (20-m depth) portions of the shallow aquifer (Table 1a). Samples were analyzed for major cations $\left(\mathrm{Ca}^{2+}, \mathrm{Mg}^{2+}, \mathrm{Na}^{+}, \mathrm{K}^{+}\right)$and anions $\left(\mathrm{SO}_{4}^{2-}, \mathrm{Cl}^{-}, \mathrm{NO}_{3}^{-}\right)$by ion chromatography using a Dionex DX-600 ${ }^{\circledR}$. Selected trace element concentrations (e.g., As, B, Ba, Co, Cu, Mo, $\mathrm{Ni}, \mathrm{Sr}, \mathrm{V}, \mathrm{U}, \mathrm{Zn}$ ) were measured by inductively coupled plasma mass spectrometry (ICP-MS; ThermoElectron Series X). Dissolved $\mathrm{O}_{2}, \mathrm{pH}$, and Eh were measured in the field using a Horiba U-22 ${ }^{\circledR}$ water quality parameter field meter. The $\mathrm{O}$ isotopic composition of groundwater and surface water samples was determined using the $\mathrm{CO}_{2}$-equilibration method on a VG Prism II ${ }^{\circledR}$ or GV Instruments IsoPrime isotope ratio mass spectrometer and are reported in \%o values relative to Vienna Standard Mean Ocean Water (VSMOW), with an analytical uncertainty of $\pm 0.1 \%$. Dissolved inorganic $C$ (DIC) and its C isotope composition were determined using the automated DIC-DOC-IRMS technique (St-Jean, 2003) consisting of an OI Analytical Model 1030 Carbon analyzer and a GV Instruments IsoPrime mass spectrometer. Carbon isotope compositions $\left({ }^{13} \mathrm{C} /{ }^{12} \mathrm{C}\right)$ are reported in \%o relative to the Vienna Peedee Belemnite (VPDB) standard, with an analytical uncertainty of $\pm 0.3 \%$. Dissolved organic $\mathrm{C}$ (DOC) was analyzed using the carbon analyzer in wet oxidation mode.

Groundwater age dating by the ${ }^{3} \mathrm{He} /{ }^{3} \mathrm{H}$ method has been applied as an aid in quantifying flow and transport on the aquifer scale in a number of studies (e.g., Ekwurzel et al., 1994; Poreda et al., 1988; Solomon et al., 1992). Under this technique, groundwater samples are assigned an apparent age, $t$, based upon measured abundances of ${ }^{3} \mathrm{H}$ and its daughter product, tritiogenic $\mathrm{He}$ $\left({ }^{3} \mathrm{He}_{\text {trit }}\right)$

$t$, years $=-17.8 \times \ln \left(1+{ }^{3} \mathrm{He}_{\text {trit }} /{ }^{3} \mathrm{H}\right)$

As part of the age calculation, the measured concentration of ${ }^{3} \mathrm{He}$ must be corrected for components not related to ${ }^{3} \mathrm{H}$ decay (Aeschbach-Hertig et al., 1999; Ekwurzel, 2004; Ekwurzel et al., 1994). The resulting calculated groundwater age represents the mean apparent age of the sample subjected to mixing along the flow path from points of recharge to the well screen (Weissmann et al., 2002). The inferred age represents only the age of the portion of the water sample that contains measurable ${ }^{3} \mathrm{H}$; samples with a ${ }^{3} \mathrm{H}$ abundance that is too low for accurate age determination (less than one picocurie/L) are regarded as "pre-modern", or greater than 50 a in age.

For ${ }^{3} \mathrm{H} /{ }^{3} \mathrm{He}$ age dating, sample handling and processing included collection of groundwater samples containing dissolved noble

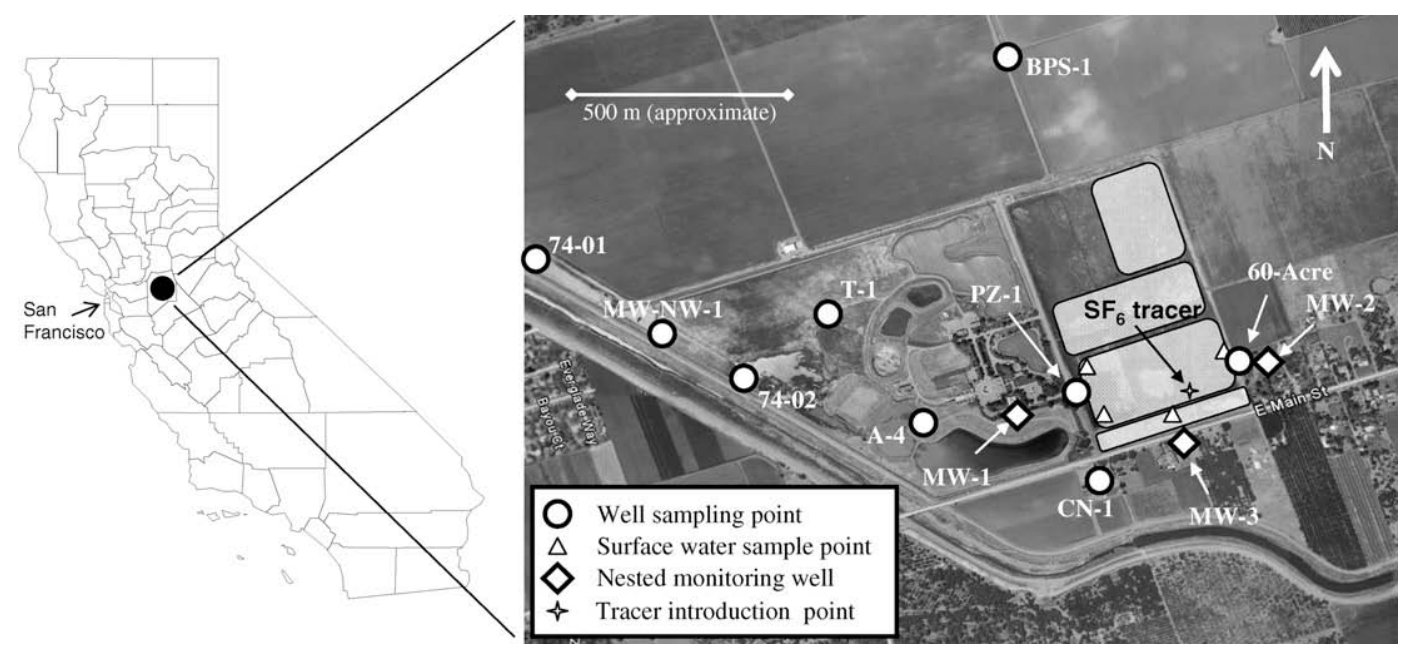

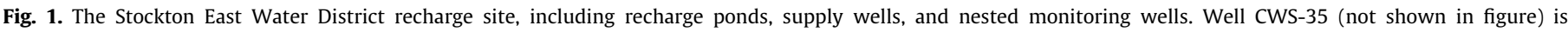
approximately $1500 \mathrm{~m}$ WNW of the recharge pond. 
Table 1a

Recharge indicator and major cation and anion concentrations (mmol/L), August 2006 sampling round. “-” symbol denotes that a sample was not collected/analyzed.

\begin{tabular}{|c|c|c|c|c|c|c|c|c|c|c|c|c|c|c|c|}
\hline Well & $\begin{array}{l}\text { Screen } \\
\text { depth } \\
(\mathrm{m})\end{array}$ & $\begin{array}{l}\text { Max tracer } \\
\text { response }\left(C / C_{0}\right) \text {, } \\
\text { January. through } \\
\text { November. } 2008\end{array}$ & $\begin{array}{l}{ }^{3} \mathrm{H} /{ }^{3} \mathrm{He} \\
\text { Age (yrs), } \\
\text { August. } \\
2006\end{array}$ & $\begin{array}{l}\text { Pre-modern } \\
\text { fraction, } \\
\text { August. } \\
2006(\%)\end{array}$ & $\begin{array}{l}\delta^{18} \mathrm{O} \\
(\% o)\end{array}$ & $\begin{array}{l}\delta^{13} \mathrm{C} \\
(\%) \\
\mathrm{DIC}\end{array}$ & $\mathrm{pH}$ & $\mathrm{Cl}^{-}$ & $\mathrm{NO}_{3}^{-}$ & $\mathrm{SO}_{4}^{2-}$ & DIC & $\mathrm{Na}^{+}$ & $\mathrm{K}^{+}$ & $\mathrm{Ca}^{2+}$ & $\mathrm{Mg}^{2+}$ \\
\hline 60-Acre & $?->38$ & 0.18 & $0 \pm 1$ & 24 & -9.9 & -13.2 & 6.7 & 0.14 & 0.01 & 0.12 & 1.67 & 0.61 & 0.06 & 0.22 & 0.21 \\
\hline $74-01$ & 64-157 & $<0.00005$ & $30 \pm 2$ & 84 & -8.0 & -14.8 & 6.7 & 0.29 & 0.10 & 0.20 & 4.05 & 0.83 & 0.16 & 0.72 & 0.58 \\
\hline 74-02 & $61-152$ & $<0.00005$ & $48 \pm 1$ & 98 & -8.3 & -15.7 & 6.8 & 0.33 & 0.08 & 0.20 & 4.17 & 1.22 & 0.11 & 0.67 & 0.58 \\
\hline A-4 & $?->37$ & $<0.00005$ & $0 \pm 4$ & 41 & -8.9 & -17.5 & 6.7 & 0.42 & 0.16 & 0.26 & 6.35 & 1.22 & 0.11 & 1.12 & 0.99 \\
\hline BPS-1 & $91-143$ & - & $25 \pm 2$ & 82 & -8.3 & - & 6.7 & 0.44 & 0.21 & 0.31 & 5.67 & 1.00 & 0.17 & 1.07 & 0.91 \\
\hline $\mathrm{CN}-1$ & $?$ & 0.0007 & $10 \pm 1$ & 27 & -9.1 & -13.2 & 6.7 & 0.15 & 0.02 & 0.15 & 2.44 & 0.65 & 0.11 & 0.37 & 0.33 \\
\hline CWS-35 & $?$ & - & $37 \pm 2$ & 92 & -8.1 & -13.6 & 6.8 & 0.21 & 0.05 & 0.14 & 2.98 & 0.61 & 0.12 & 0.52 & 0.45 \\
\hline MW-1A & $11-15$ & 0.00010 & $0 \pm 1$ & 18 & -9.0 & - & 6.7 & 0.36 & 0.22 & 0.30 & 9.61 & 2.61 & 0.10 & 1.47 & 1.23 \\
\hline MW-1B & $15-20$ & 0.00006 & $0 \pm 4,0 \pm 3$ & 18,20 & -9.7 & - & 6.7 & 0.19 & 0.08 & 0.18 & 5.06 & 1.57 & 0.07 & 0.67 & 0.58 \\
\hline MW-1C & $23-28$ & 0.00006 & $0 \pm 2$ & 4 & -10.2 & -14.4 & 6.4 & 0.09 & 0.01 & 0.09 & 2.66 & 0.74 & 0.06 & 0.25 & 0.21 \\
\hline$M W-2 A$ & $9-13$ & 0.0063 & $0 \pm 2$ & 14 & -9.2 & - & 6.6 & 0.72 & 0.28 & 0.25 & 4.16 & 1.70 & 0.06 & 0.65 & 0.53 \\
\hline MW-2B & $14-17$ & 0.0065 & $0 \pm 1$ & 6 & -9.1 & -13.4 & 7.0 & 0.45 & 0.03 & 0.20 & 2.84 & 1.35 & 0.08 & 0.50 & 0.37 \\
\hline $\mathrm{MW}-2 \mathrm{C}$ & $20-24$ & 0.0003 & $3 \pm 2$ & 19 & -8.6 & -12.4 & 6.7 & 0.17 & 0.01 & 0.12 & 2.99 & 1.00 & 0.06 & 0.37 & 0.33 \\
\hline$M W-3 A$ & $9-12$ & 0.019 & $0 \pm 2$ & 13 & -8.5 & -13.3 & 7.0 & 0.13 & 0.04 & 0.16 & 2.65 & 1.04 & 0.06 & 0.42 & 0.33 \\
\hline MW-3B & $13-16$ & 0.048 & $2 \pm 1$ & 11 & -8.3 & -13.8 & 6.9 & 0.11 & 0.01 & 0.13 & 2.23 & 0.91 & 0.07 & 0.32 & 0.25 \\
\hline MW-3C & $21-26$ & 0.11 & $0 \pm 1$ & 13 & -7.9 & -14.4 & 6.8 & 0.15 & 0.01 & 0.17 & 1.94 & 0.91 & 0.06 & 0.27 & 0.21 \\
\hline MW-NW-1 & $17-24$ & - & $0 \pm 2,0 \pm 3$ & 29,32 & -8.5 & -13.9 & 6.8 & 0.13 & 0.03 & 0.11 & 2.94 & 0.57 & 0.04 & 0.57 & 0.41 \\
\hline PZ-1 & $12-20$ & 0.27 & $2 \pm 1,0 \pm 1$ & 26,32 & -9.8 & -12.7 & 7.0 & 0.08 & 0.01 & 0.09 & 1.53 & 0.35 & 0.06 & 0.30 & 0.25 \\
\hline $\mathrm{T}-1$ & $?$ & $<0.00005$ & $3 \pm 1$ & 14 & -8.0 & -15.1 & 6.8 & 0.55 & 0.20 & 0.33 & 5.19 & 1.65 & 0.09 & 0.97 & 0.82 \\
\hline Pond-2A & - & 1 & - & - & -11.7 & -7.4 & 7.1 & 0.03 & $<0.003$ & 0.03 & 0.53 & 0.09 & 0.02 & 0.08 & 0.12 \\
\hline
\end{tabular}

gases in Cu tubes filled to prevent exposure to the atmosphere and sealed with a cold weld in the field. Dissolved noble gas concentrations were measured after gas extraction on a vacuum manifold and cryogenic separation of the noble gases using a quadrupole mass spectrometer. The ratio of ${ }^{3} \mathrm{He}$ to ${ }^{4} \mathrm{He}$ was measured on a VG5400 mass spectrometer. Tritium was determined independently by measuring ${ }^{3} \mathrm{He}$ accumulation after vacuum degassing 0.5-L groundwater samples following a 3- to 4-week accumulation time. The resulting typical analytical error for groundwater age determination is \pm 1 a.

\subsection{Tracer study}

Tracer studies have been previously employed as a means of understanding transport near managed recharge facilities (Clark et al., 2004; Gamlin et al., 2001; Quast et al., 2006). The tracer injection experiment entailed bubbling $\mathrm{SF}_{6}$ gas into a 12-in. (0.3$\mathrm{m}$ ) diameter inlet pipe that delivered water to one of the main infiltration ponds (Fig. 1). Injection of the tracer occurred between January 17th and February 1st, 2007, with sampling and analysis of groundwater samples from surrounding wells occurring over the subsequent 6 months. The tracer introduction was timed to roughly coincide with a change in the imported water source from New Melones (Stanislaus River) water to New Hogan (Calaveras River) water.

Sulfur hexafluoride was introduced using a gas cylinder with a standard regulator and a mass flow controller that maintained the gas flow rate at $10 \mathrm{~cm}^{3} / \mathrm{min}$. Vertical mixing of the tracer in the pond water column depends on the presence/absence of a thermocline, while the degree of horizontal mixing within the pond depends largely on wind duration and speed. The maximum tracer concentration and the retention time of the tracer in the surface water body are therefore dependent upon a number of environmental factors and are thus difficult to predict a priori.

Analyses of water samples for dissolved $\mathrm{SF}_{6}$ involved extracting a known amount of sample, typically $40-43 \mathrm{~g}$, with $10 \mathrm{~mL} \mathrm{SF}_{6}$-free air in a gas-tight syringe and analyzing the headspace by gas chromatography (GC). Analyses were performed using a Hewlett-Packard 5890 Series II gas chromatograph equipped with a model G1223A electron capture detector (ECD). The GC has a calculated detection limit of $0.6 \mathrm{ppt}$. Extrapolation of the low level calibration curve with the intercept forced through the origin was used to quantify samples below 9.3 ppt but the reporting limit was set at $10 \mathrm{ppt} \mathrm{SF}_{6}$ in the extracted headspace. A set of seven calibration check standards was used to monitor system stability and selected samples were run in replicate.

\subsection{Geochemical modeling}

Changes in water quality parameters as a result of mixing of imported recharge water and groundwater were interpreted with the aid of the PHREEQC geochemical model (Parkhurst and Appelo, 2002). For this study, PHREEQC and its accompanying complexation constant data sets were used to postulate a geochemical model of recharge water-aquifer interactions in the presence of both an ion exchanger and a hydrous ferric oxide phase with a population of active complexation sites, each specified to be in equilibrium with an end-member groundwater composition as an initial condition. The MIX feature of PHREEQC was used to predict the equilibrium concentrations of major ions, trace elements, and $\mathrm{pH}$ in response to the incremental displacement of end-member groundwater by recharge water (up to one pore volume) while the mixture was maintained in equilibrium with aquifer mineral surfaces.

\section{Results}

\subsection{Tracer response, groundwater age, and stable isotope data}

Stable isotope data, groundwater ages, tracer test response, and major and minor ion chemistry for each of the wells sampled during the August 2006 sampling round are summarized in Tables 1a and $1 \mathrm{~b}$. From the start of the tracer injection on January 17 through June of 2007, significant tracer responses (i.e., greater than approximately 1 part in 100 of the original $\mathrm{SF}_{6}$ concentration introduced in the pond) were observed in wells PZ-1, 60-Acre, MW-3B, and MW-3C (Fig. 2); well MW-3A exhibited a similar responses by July. Much lower tracer concentrations (on the order of 1 part in 1000 of the maximum pond concentration) were observed in wells $\mathrm{CN}-1$, MW-1A, MW-1B, MW-1C, MW-2A, MW-2B, and MW-2C. Peak tracer arrival times ranged from weeks for wells closest to the pond (PZ-1 and 60-acre) to several months for wells at a greater distance 
Table 1b

Trace element concentrations ( $\mu \mathrm{mol} / \mathrm{L})$, August 2006 sampling round.

\begin{tabular}{|c|c|c|c|c|c|c|c|c|c|c|c|}
\hline Well & As & B & $\mathrm{Ba}$ & $\mathrm{Cu}$ & Mn & Mo & $\mathrm{Ni}$ & $\mathrm{Sr}$ & U & V & $\mathrm{Zn}$ \\
\hline 60-Acre & 0.10 & 2.96 & 0.28 & 0.005 & 0.046 & 0.011 & 0.007 & 1.20 & 0.001 & 0.90 & $<0.006$ \\
\hline 74-01 & 0.08 & 3.79 & 1.01 & 0.013 & 0.017 & 0.004 & 0.007 & 4.02 & 0.007 & 0.37 & 0.04 \\
\hline 74-02 & 0.15 & 4.72 & 1.76 & 0.046 & 5.024 & 0.006 & 0.012 & 3.89 & 0.004 & 0.20 & 0.03 \\
\hline A-4 & 0.07 & 3.61 & 1.39 & $<0.004$ & 0.026 & 0.006 & 0.020 & 5.91 & 0.018 & 0.71 & 0.01 \\
\hline BPS-1 & 0.05 & 4.90 & 1.34 & 0.041 & $<0.004$ & 0.003 & 0.012 & 5.82 & 0.017 & 0.45 & 0.18 \\
\hline $\mathrm{CN}-1$ & 0.09 & 3.79 & 0.46 & 0.022 & 0.027 & 0.006 & 0.007 & 2.18 & 0.002 & 0.43 & 0.28 \\
\hline CWS-35 & 0.10 & 3.24 & 0.92 & 0.066 & 0.018 & 0.006 & 0.007 & 2.84 & 0.003 & 0.45 & 0.09 \\
\hline MW-1A & 0.05 & 7.49 & 1.38 & 0.006 & 0.020 & 0.006 & 0.029 & 7.89 & 0.035 & 0.53 & 0.01 \\
\hline MW-1B & 0.08 & 6.38 & 0.79 & 0.005 & $<0.002$ & 0.006 & 0.010 & 3.44 & 0.010 & 0.86 & $<0.004$ \\
\hline MW-1C & 0.11 & 4.44 & 0.40 & $<0.004$ & $<0.007$ & 0.010 & 0.010 & 1.27 & 0.001 & 1.04 & 0.02 \\
\hline MW-2A & 0.06 & 4.53 & 0.79 & 0.006 & 0.032 & 0.013 & 0.019 & 3.56 & 0.008 & 0.75 & 0.06 \\
\hline MW-2B & 0.07 & 4.63 & 0.27 & 0.005 & 0.008 & 0.013 & 0.015 & 3.50 & 0.003 & 0.73 & $<0.01$ \\
\hline MW-2C & 0.07 & 3.89 & 0.44 & 0.005 & 0.015 & 0.010 & 0.012 & 1.94 & 0.002 & 0.82 & 0.14 \\
\hline MW-3A & 0.09 & 5.55 & 0.45 & 0.009 & $<0.004$ & 0.010 & 0.017 & 2.04 & 0.002 & 0.84 & $<0.01$ \\
\hline MW-3B & 0.09 & 4.53 & 0.12 & 0.006 & 0.244 & 0.010 & 0.012 & 1.72 & 0.001 & 0.80 & 0.02 \\
\hline MW-3C & 0.12 & 3.33 & 0.31 & 0.017 & 0.019 & 0.011 & 0.010 & 1.35 & 0.001 & 1.00 & 0.03 \\
\hline MW-NW-1 & 0.05 & 2.41 & 0.71 & 0.008 & $<0.004$ & 0.005 & 0.009 & 2.69 & 0.002 & 0.63 & $<0.006$ \\
\hline PZ-1 & 0.09 & 2.50 & 0.33 & 0.008 & 0.011 & 0.009 & 0.009 & 1.48 & 0.000 & 0.84 & $<0.012$ \\
\hline $\mathrm{T}-1$ & 0.06 & 5.18 & 1.33 & 0.020 & 0.036 & 0.007 & 0.017 & 5.18 & 0.011 & 0.71 & 0.02 \\
\hline Pond-2A & 0.01 & 0.56 & 0.16 & 0.013 & 0.007 & 0.002 & 0.007 & 0.60 & 0.000 & 0.02 & $<0.003$ \\
\hline
\end{tabular}

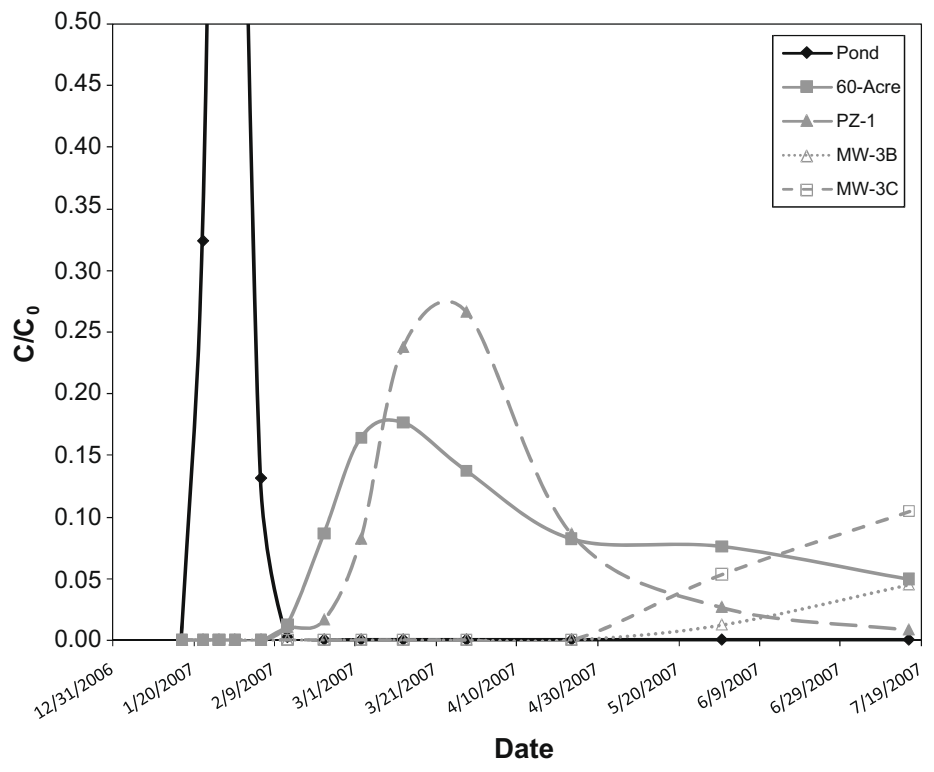

Fig. 2. Sulfur hexafluoride tracer response curves observed through July 2007 in wells proximal to the SW pond following January tracer injection.

from the pond (e.g., MW-3 and CN-1). Mean apparent groundwater ages for wells adjacent to the ponds (PZ-1, 60-acre, MW-1A, MW1B, MW-1C, MW-2A, MW-2B, MW-2C, MW-3A, MW-3B, and MW3C) were all determined to be less than 2 a (Table $1 \mathrm{a}$ ), indicating that the ${ }^{3} \mathrm{H}$-containing portion of the produced groundwater is transported to the capture zone of these wells over a short time scale. Groundwater sampled from well T-1, which is further from the ponds but screened in alluvium, was found to have a mean apparent age of 3a. In addition to the recently recharged portion of the groundwater, many of these wells tap ambient groundwater that recharged more than several decades ago which does not now contain ${ }^{3} \mathrm{H}$; i.e., "pre-modern water". The pre-modern fraction was determined using previously measured precipitation ${ }^{3} \mathrm{H}$ concentrations associated with atmospheric nuclear testing versus recharge year and comparing a sample's measured ${ }^{3} \mathrm{H}$ to the ${ }^{3} \mathrm{H}$ expected based on the ${ }^{3} \mathrm{H} /{ }^{3} \mathrm{He}$ age of the sample (Manning and Thiros, 2005; Moran et al., 2004).

Dividing the groundwater samples into two groups based on tracer response serves as a means of identifying water quality re- sponses related to pond recharge. Several measured parameters indicate that waters where a tracer response was observed contain significant fractions of pond recharge water:

1. The fraction of pre-modern water is generally larger in those wells with a minimal tracer response - 74-01, 74-02, A-4 - than in those wells characterized by a significant tracer response; i.e., $C / C_{0}>5 \times 10^{-5}$, the effective detection limit for the $\mathrm{SF}_{6}$ tracer (Table 1a). Although tracer data were not available for wells BPS-1 and CWS-35, the relatively deep screen depth for BPS-1 and the $1500-\mathrm{m}$ distance from the tracer injection point to CWS-35, along with the high proportion of pre-modern water for both wells, suggest BPS-1 and CWS-35 should also be included in this group.

2. The relationship of sampled water $\delta^{18} \mathrm{O}$ and total dissolved solids (TDS) content to tracer response and to one another is also consistent with the presence of a significant fraction of recharge water in groundwater samples that exhibit tracer response (Fig. 3). Groundwater $\delta^{18} \mathrm{O}$ is an indicator of imported water, as 


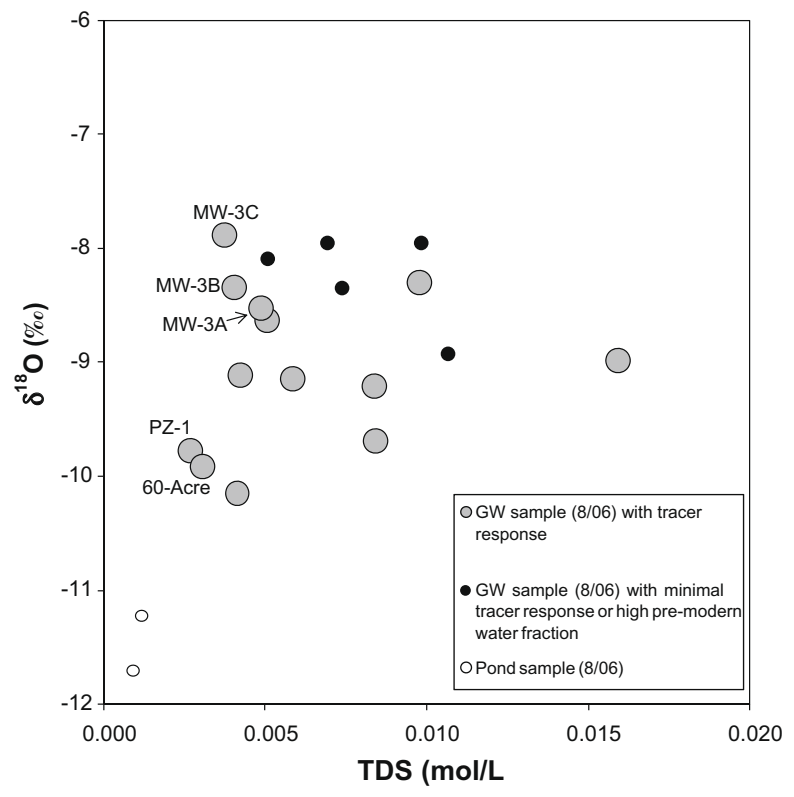

Fig. 3. Relationship between $\delta^{18} \mathrm{O}$ and total dissolved solids (TDS) in groundwater samples and surface water samples collected during the August 2006 sampling round. Wells that later exhibited only minimal tracer response during the subsequent 2007 test, or are otherwise characterized by a high proportion of premodern water, are plotted as small solid circles. In contrast, those wells with a pronounced tracer response $\left(C / C_{0}>0.01\right)$ plotted as large solid circles and are labeled with their name.

values of $\delta^{18} \mathrm{O}$ associated with surface water supplies originating in the Sierra Nevada are isotopically light (enriched in ${ }^{16} \mathrm{O}$ relative to ${ }^{18} \mathrm{O}$ ) in comparison to those of local groundwater as a result of cooler precipitation temperatures, higher elevation, and greater distance along Pacific storm tracks (Rose et al., 1996). Analysis of two pond samples collected in August 2006 yielded $\delta^{18} \mathrm{O}$ values of $-11.2 \%$ and $-11.7 \%$, reflecting the comparatively high-elevation New Melones reservoir water (originating largely as snowmelt), while other groundwater samples, presumably recharged from local precipitation and runoff, are characterized by an end member $\delta^{18} \mathrm{O}$ value close to $-8 \%$ (Fig. 3). New Hogan water, which was first introduced to the recharge ponds in January 2007, originates mainly as rainwater and has a $\delta^{18} \mathrm{O}$ value of $-8 \%$, similar to the local groundwater. For this reason, the August 2006 sample set provides the best separation of local water and recharge pond water based on $\delta^{18} \mathrm{O}$, since it predates the introduction of New Hogan water, and integrates several years of applied New Melones water. TDS is also an indicator of recharge because of very low concentrations of major cations and anions in the recharge pond water as compared to local groundwater ("TDS" is defined in this study as the sum of the molar concentrations of $\mathrm{Cl}^{-}, \mathrm{HCO}_{3}^{-}, \mathrm{SO}_{4}^{2-}, \mathrm{NO}_{3}^{-}, \mathrm{Na}^{+}, \mathrm{K}^{+}, \mathrm{Ca}^{2+}$, and $\mathrm{Mg}^{2+}$ to facilitate comparison with model results). The relationship between these two indicators of recharge water is demonstrated by the generally lower $\delta^{18} \mathrm{O}$ values in wells exhibiting some degree of tracer response and the comparatively low TDS values in wells exhibiting the most pronounced tracer response $\left(C / C_{0}>0.01\right)$. Nonetheless, there is clearly scatter in the data, suggesting that the mixing process is complex and may depend on transient conditions of groundwater flow in response to local pumping and recharge operations. It is also plausible that much of this scatter could be associated with the variety of wells and well screen lengths encountered at the site.

3. An indication of the presence of recharge water in some groundwater samples is suggested in the relationship between $\delta^{13} \mathrm{C}$ and TDS, again appearing more definitive when the tracer response is taken into account (Fig. 4). A likely explanation of this inverse correlation involves the mixing of imported surface water $\left(\delta^{13} \mathrm{C}\right.$ values of -11 to-4\%o $)$ with local groundwater characterized by lower $\delta^{13} \mathrm{C}$ values $(-18$ to $-16 \%$ ), the latter possibly influenced by biogeochemical processes involving soil $\mathrm{CO}_{2}$. As such, the $\mathrm{C}$ isotope composition of DIC - which strongly correlates with TDS (Table 1a) - differentiates local water that has recharged through a soil zone (low $\delta^{13} \mathrm{C}$ values) from imported water that has recharged through the ponds. The DOC in the pond water is relatively low, ranges from 1.3 to $3.9 \mathrm{mg} / \mathrm{L}$ as C, so the increase in DIC (Table 1a) and the decrease in $\delta^{13} \mathrm{C}$ observed in groundwater wells cannot be attributable solely to decomposition of organic matter (Kortelainen and Karhu, 2006).

\subsection{Geochemistry}

The chemical composition of groundwater containing some fraction of pond recharge cannot be explained by simple binary mixing between pond water and ambient groundwater. Mass-exchange between recharging water and aquifer material is required to explain the following patterns:

1. Groundwater samples exhibit a relative enrichment in $\mathrm{Na}$ and $\mathrm{K}$ at the expense of $\mathrm{Ca}$ and $\mathrm{Mg}$ when compared to the imported recharge water composition. Significantly, this tendency is most pronounced in those wells characterized by a definitive tracer response, with the exception of PZ-1 (Fig. 5).

2. The concentrations of three trace elements - As, V, and Mo - are comparatively elevated in groundwater samples which have been impacted by recharge water despite occurring in vanishingly low concentrations in the recharge water composition itself (Figs. 6-8, respectively). While the correlation with the recharge water fraction for $\mathrm{V}$ and $\mathrm{Mo}$, as indicated by either

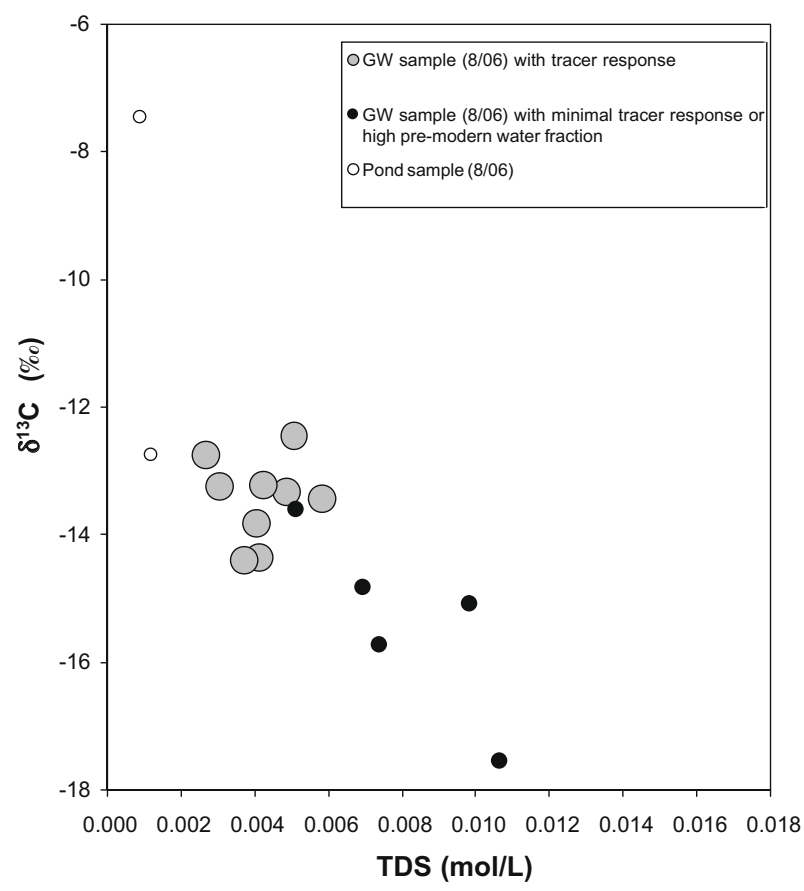

Fig. 4. Relationship between $\delta^{13} \mathrm{C}$ (for DIC) and total dissolved solids (TDS) in groundwater samples and surface water samples collected during the August 2006 sampling round. Wells that later exhibited only minimal tracer response, or are otherwise characterized by a high proportion of pre-modern water, are indicated. 


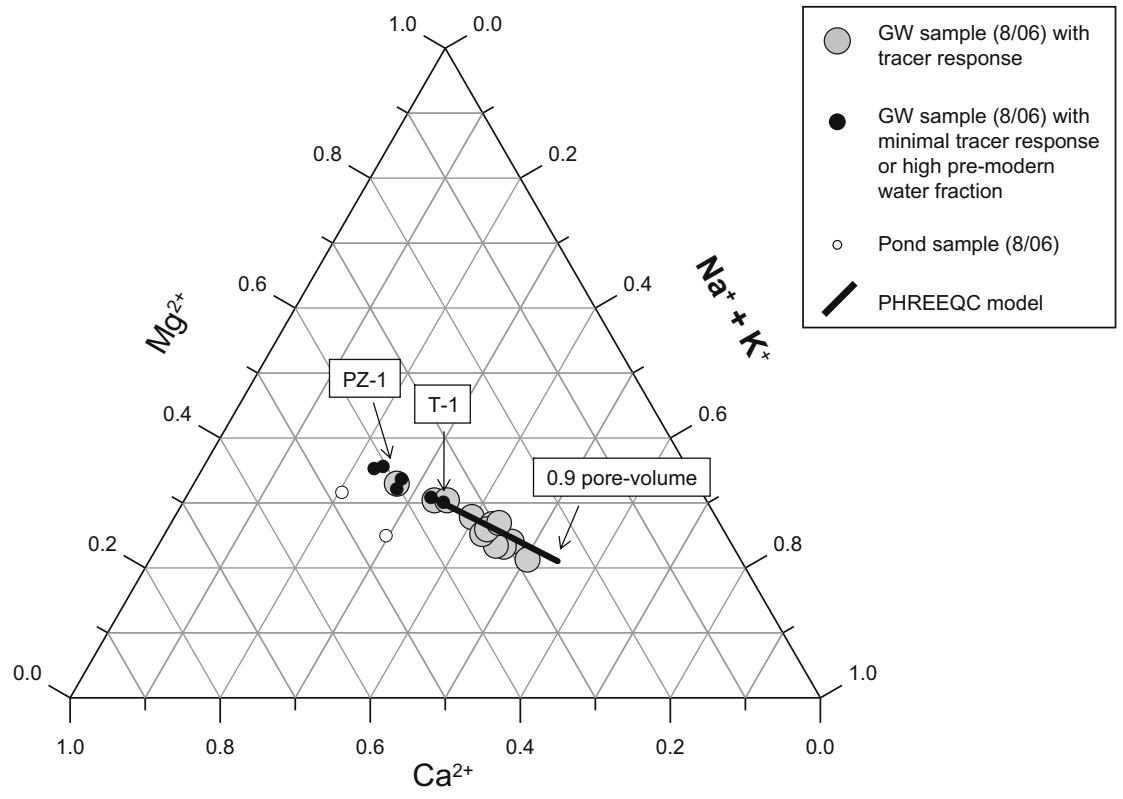

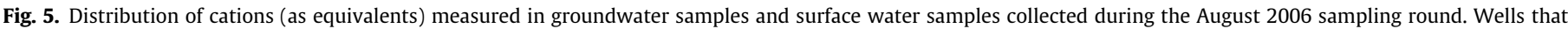

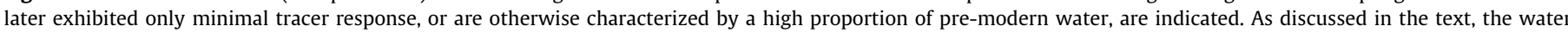

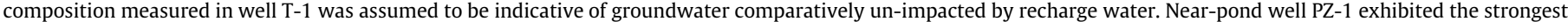
tracer response.

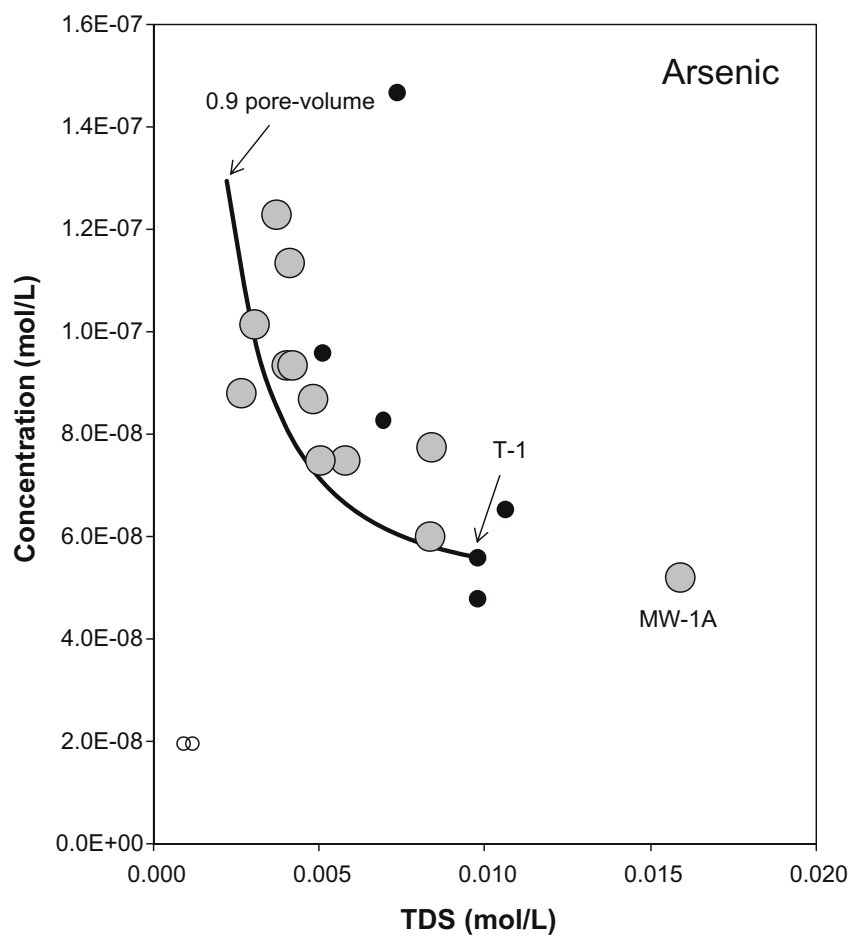

- GW sample (8/06) with tracer response
or high pre-modern water fraction
O Pond sample (8/06)
- PHREEQC model

Fig. 6. Relationship between dissolved As and total dissolved solids (TDS) in groundwater samples and surface water samples collected during the August 2006 sampling round. Wells that later exhibited only minimal tracer response, or are otherwise characterized by a high proportion of pre-modern water, are indicated. Geochemical modeling results reflect the flushing of up to 0.9 pore volume of recharge water through ambient aquifer conditions, which are defined as being in equilibrium with the T-1 water composition.

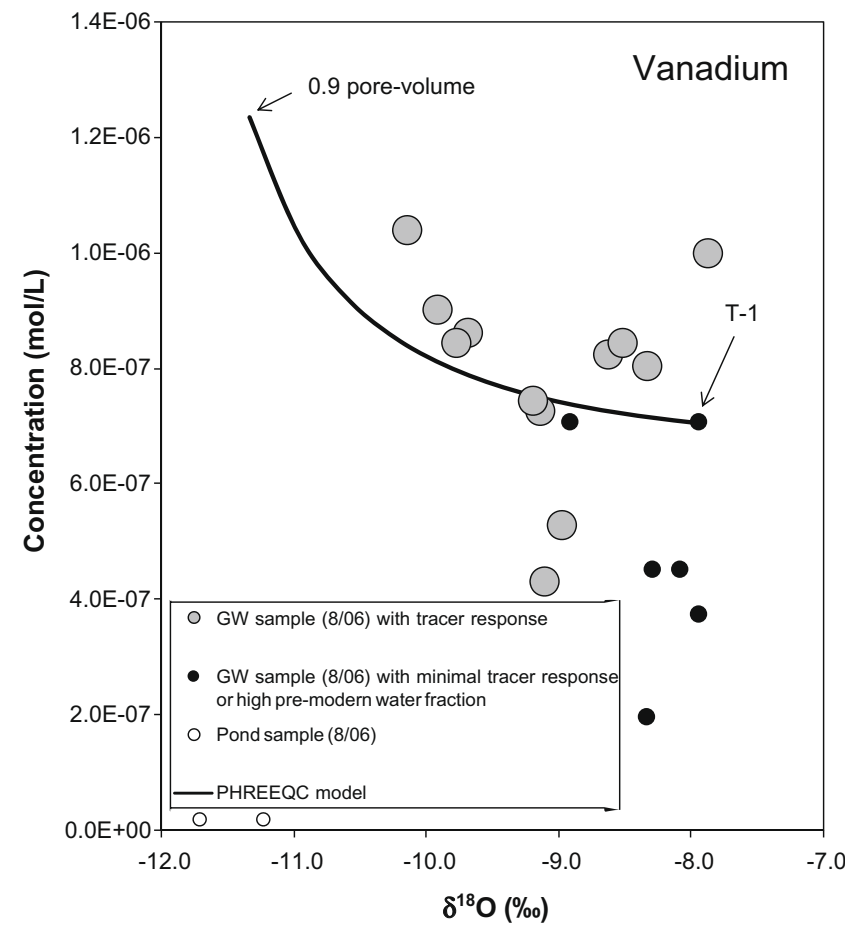

Fig. 7. Relationship between dissolved $\mathrm{V}$ and $\delta^{18} \mathrm{O}$ in groundwater samples and surface water samples collected during the August 2006 sampling round. Wells that later exhibited only minimal tracer response, or are otherwise characterized by a high proportion of pre-modern water, are indicated. Geochemical modeling results indicate a general increase in $\mathrm{V}$ concentration with recharge water fraction, up to 0.9 pore volumes.

$\delta^{18} \mathrm{O}$ or TDS, is comparatively poor, the differences in the concentrations of these elements between wells with a tracer response and those without is evident.

To explain these reactions, a geochemical model was developed to study the mixing of recharge water with background 


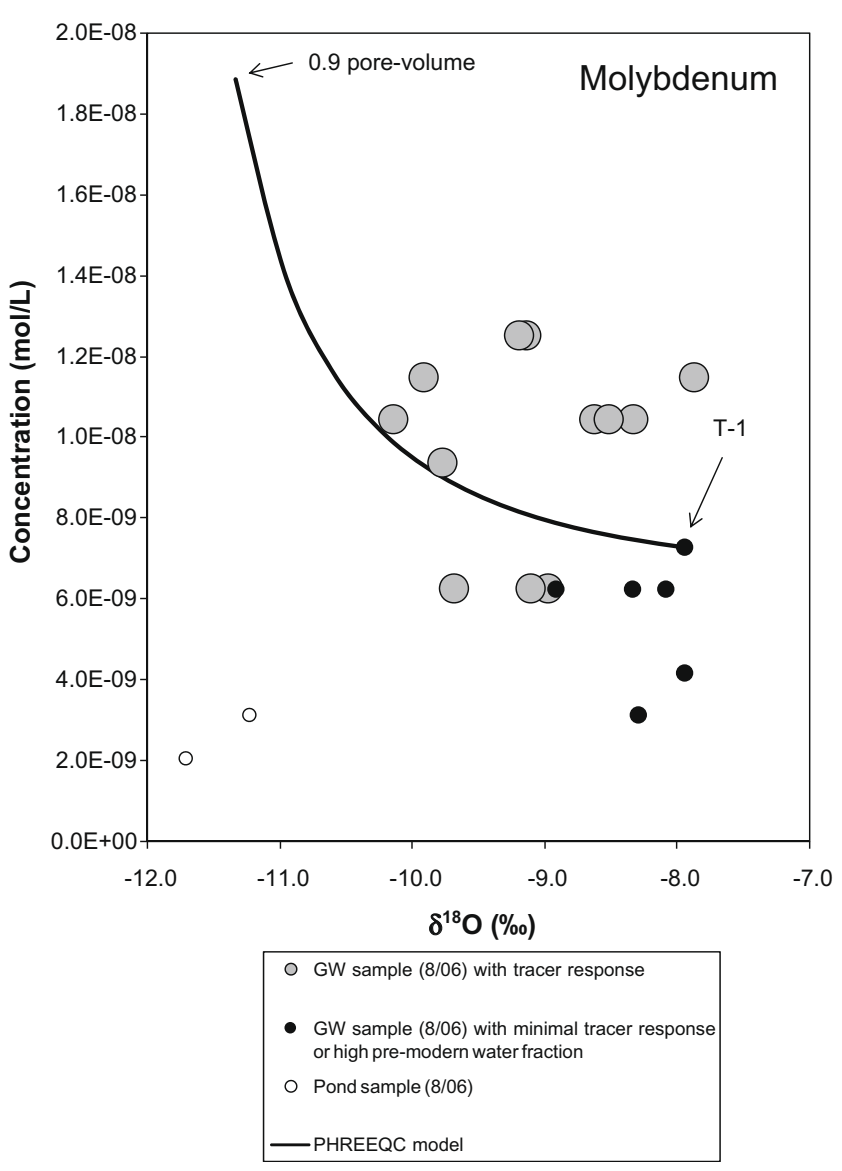

Fig. 8. Relationship between dissolved Mo and $\delta^{18} \mathrm{O}$ in groundwater samples and surface water samples collected during the August 2006 sampling round. Wells that later exhibited only minimal tracer response, or are otherwise characterized by a high proportion of pre-modern water, are indicated. Geochemical modeling results indicate a general increase in $\mathrm{V}$ concentration with recharge water fraction, up to 0.9 pore volumes.

groundwater in the presence of aquifer materials. For the SEWD site, negative log saturation indices were calculated for site groundwater compositions for common buffering mineral species such as calcite. The principal modeled water-aquifer material interactions involved (1) ion exchange reactions and (2) complexation reactions on hydrous ferric oxide (HFO) phases. For ion exchange, PHREEQC employs a reaction formulation that assumes equivalent fractions for activities of exchange sites in the overall geochemical model (Gaines and Thomas, 1953) of the form

$\mathrm{Ca}^{2+}+2 \mathrm{X}^{-} \leftrightarrow \mathrm{CaX}_{2}$

where $\mathrm{X}$ represents an exchange site. Equilibrium cation exchange constants for major cations (e.g., $\mathrm{Ba}^{2+}, \mathrm{Ca}^{2+}, \mathrm{Cu}^{2+}, \mathrm{K}^{+}, \mathrm{Mg}^{2+}, \mathrm{Na}^{+}$ $\mathrm{Sr}^{2+}$, and $\mathrm{Zn}^{2+}$ ) are included in the PHREEQC.DAT database from various sources (Appelo and Postma, 1993). The cation exchange conceptualization requires that the overall abundance of such exchange sites must be specified in the model definition. Independent measurements of cation exchange capacity (CEC) for site materials were not available, so a postulated value that produced reasonable model agreement with site data, as discussed below, was selected. A total of $0.5 \mathrm{~mol}$ of exchange sites were assumed to be available per liter of groundwater, equivalent to a CEC on the order of $0.08 \mathrm{~mol}$ of charge $/ \mathrm{kg}$, a value that is reasonable for alluvial materials (e.g., Sposito, 1989). No adjustments were made to the cation exchange complexation constants provided in the PHREEQC.DAT default data set.
PHREEQC also employs the database developed by Dzombak and Morel (1990) to quantify complexation of trace elements onto an HFO surface. This model assumes "strong" and "weak" binding sites, with abundances of 0.2 mole of weak sites and 0.005 mole of strong sites per mole of $\mathrm{Fe}(\mathrm{III})$. Pertinent data include binding site complexation constants for $\mathrm{As}, \mathrm{Ba}, \mathrm{B}, \mathrm{Ca}, \mathrm{Cu}, \mathrm{Mg}, \mathrm{Mo}, \mathrm{Ni}, \mathrm{U}, \mathrm{V}$, and $\mathrm{Zn}$. For this study, 0.1 mole of reactive solid-phase $\mathrm{Fe}(\mathrm{III}) / \mathrm{L}$ of groundwater was used to provide a reasonable fit to the trace element data, as discussed below. This corresponds to a weight percent abundance of reactive ferric oxyhydroxide as $\mathrm{Fe}(\mathrm{OH})_{3}$ or $\mathrm{FeOOH}$ per unit mass of aquifer material on the order of $0.1-$ $0.2 \%$. No adjustments were made to the complexation constant values provided in the Dzombak and Morel (1990) data set. Redox processes, which could affect complexation onto an HFO surface by altering the chemistry of the solutes as well as the abundances of complexation sites, were not considered as dissolved $\mathrm{O}$ and redox potential measurements obtained during sampling were not indicative of anaerobic conditions; low Mn concentrations (Table 1b) among the shallow groundwater samples (e.g., excluding wells 74-01 and 74-02) also support the assumption of generally aerobic conditions.

Definition of a background groundwater composition is required for use as (1) an end-member in the mixing calculations and (2) as a basis for an initial putative equilibration distribution of species among the ion exchange and HFO surface complexation sites on the solid aquifer material. Well T-1 was chosen as a bestcandidate shallow background well because it did not exhibit a definitive tracer response and yet is characterized by a comparatively low pre-modern water fraction (Table 1a). Its low $\delta^{13} \mathrm{C}$ value of $-15.1 \%$ o (Table $1 \mathrm{a}$ ) is also consistent with other wells that have not been appreciably impacted by imported recharge water (Fig. 4). The other mixing end member, the imported recharge water, is based on the water composition measured in pond sample $2 \mathrm{~A}$ collected during the August 2006 sampling round (Tables $1 \mathrm{a}$ and $1 \mathrm{~b}$ ).

The results of the PHREEQC modeling calculations are indicated by a solid line in Figs. 5-8, and can be compared to observed cation distribution (Fig. 5) and the trace element distributions (Fig. 6-9). Specifically, the PHREEQC results depict the change in composition from the T-1 water composition (i.e., background groundwater, or zero pore-volume shift of imported recharge water) to $90 \%$ of pore volume of imported recharge water. In this context, a one pore-volume shift would imply that the pore water in contact with the aquifer mineral assemblage has been replaced by $100 \%$ imported recharge water which has been allowed to come into equilibrium with that mineral assemblage.

The model reproduces the trend observed in the cation exchange data: the solution is preferentially enriched in $\mathrm{Na}$ and $\mathrm{K}$ from the exchanger surface in response to the low-TDS but comparatively $\mathrm{Ca}$ - and $\mathrm{Mg}$-rich imported water composition (Fig. 5). In comparison to observed trace element concentrations, the model matches the As and $U$ concentrations in tracer-impacted wells quite well (Fig. 6 and 9), given that the default Dzombak and Morel (1990) database parameters were not adjusted to match the data. The $\mathrm{V}$ and Mo concentrations measured in wells characterized by a tracer response (Figs. 7 and 8, respectively) exhibit much scatter. For these elements, the model only qualitatively captures the trend and magnitude of the concentration changes in response to mixing with recharge water. For all 4 oxyanions (As, V, Mo, and U), the model captures the most significant aspects of the observed trace metal distributions: quasi-conservative behaviour for $\mathrm{U}$, and significant release of As, $\mathrm{V}$, and Mo from aquifer solid-phases on first contact with recharged pond water.

Although the results of this geochemical model are with measurements, it is important to recognize that the idealizations used in the model can influence the interpretation of the data. The two most important potential sources of error in this regard include: 


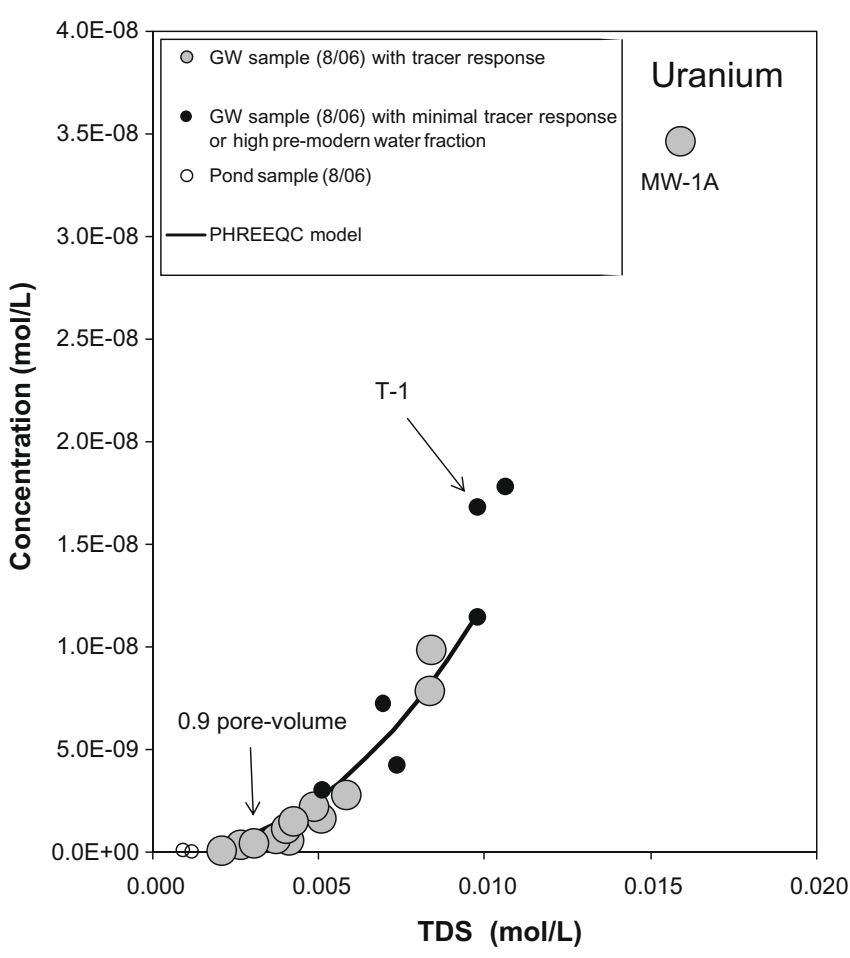

Fig. 9. Relationship between dissolved $U$ and total dissolved solids (TDS) in groundwater samples and surface water samples collected during the August 2006 sampling round. Wells which later exhibited no tracer response during the subsequent 2007 test are indicated. Unlike As, V or Mo, U concentrations decrease with increasing recharge water fraction, a trend captured by the geochemical model.

- A simplified mixing model, most notably the definition of an unimpacted groundwater end-member composition, which may not be available in reality, given the temporally variable recharge history.

- Slow adsorption-desorption kinetics and/or rate-limiting diffusive transport, both of which could act to impede the ability of the system to achieve thermodynamic equilibrium (Williams et al., 2003; Zhang and Selim, 2005) over the weeks-to-months transport time scales suggested by the tracer test data.

\section{Discussion}

For specific geochemical constituents, the introduction of recharge water to the ambient groundwater aquifer causes a shift in the relative abundances of major cations and the mobilization of certain trace elements. Among those trace elements analyzed as part of this study, only $\mathrm{As}(\mathrm{V}), \mathrm{V}, \mathrm{Mo}$, and $\mathrm{U}$ are predicted, via speciation calculations with PHREEQC, to form anionic complexes at near-neutral $\mathrm{pH}$ values, specifically $\mathrm{HAsO}_{4}^{2-}, \mathrm{HAsO}_{4}^{-}, \mathrm{H}_{2} \mathrm{VO}_{4}^{-}$, $\mathrm{MoO}_{4}^{-}, \mathrm{UO}_{2}\left(\mathrm{CO}_{3}\right)_{2}^{2-}$, and $\mathrm{UO}_{2}\left(\mathrm{CO}_{3}\right)_{3}^{4-}$. Recharge water appears to be characterized by a somewhat elevated $\mathrm{pH}$ in comparison to site groundwater, so displacement of oxyanions by $\mathrm{OH}^{-}$on the HFO binding sites is a plausible explanation for the observed behaviour of As, V, and Mo. A number of previous studies have suggested this mechanism could play a role in mobilizing As and other trace elements (Belitz et al., 2003; Izbicki, 2008; Rai and Zachara, 1984; Smedley and Kinniburgh, 2002; Welch et al., 2000).

Adsorbed As can represent a significant source of dissolved As at low concentrations (Gao et al., 2006). While soil As concentration data are not available for the SEWD site, the PHREEQC model used to speciate the site groundwater composition tacitly assumes that the aquifer material in equilibrium with the putative T-1 endmember groundwater composition harbors some $17 \mathrm{mg} / \mathrm{kg}$ of adsorbed As; i.e., implied by the assumed quantity of HFO, the Dzombak and Morel (1990) complexation constant dataset, and the concentration of As measured in the T-1 groundwater composition. Gao et al. (2004) noted As concentrations up to $24 \mathrm{mg} / \mathrm{kg}$ in sediments collected from the Tulare Lake Bed area in the southern San Joaquin Valley, much of which was leachable by repeated flushing with artificial pore water. However, the soil As concentrations reported by Belitz et al. (2003) on the order of $8-10 \mathrm{mg} / \mathrm{kg}$ or higher (for comparatively high soil As concentrations) occurring on the western side of the valley are probably more representative. In this context, the modeled value of $17 \mathrm{mg} / \mathrm{kg}$ is elevated but still plausible. Dissolved As concentrations in many of the shallow wells - those effected directly by recharge water (e.g., MW-3 cluster) - are on the order of 7-9 $\mu \mathrm{g} / \mathrm{L}(0.09-0.12 \mu \mathrm{mol} / \mathrm{L})$, whereas the putative background groundwater composition associated with well T-1 is characterized by an As concentration of approximately $4 \mu \mathrm{g} / \mathrm{L}(0.055 \mu \mathrm{mol} / \mathrm{L})$. Belitz et al. (2003) report that groundwater samples collected from alluvial fans on the western side of the San Joaquin Valley are typically characterized by As concentrations less than $5 \mu \mathrm{g} / \mathrm{L}(0.07 \mu \mathrm{mol} / \mathrm{L})$. Deeper groundwater at the SEWD site (e.g., well 74-01) and at other locations in the western San Joaquin Valley is characterized by elevated As concentrations near or above $10 \mu \mathrm{g} / \mathrm{L}(0.13 \mu \mathrm{mol} / \mathrm{L})$, which is the current federal regulatory action limit.

Observed and modeled concentrations of $U$ in comparison to TDS are shown on Fig. 9. Among the anionic trace element complexes, $\mathrm{U}$ is unique in that it does not exhibit an apparent increase in concentration stemming mixing with imported recharge water. This difference in behaviour compared to the other three trace elements is captured by the PHREEQC model. A likely reason is that Ucarbonate complexes may be comparatively weakly adsorbed. Wazne et al. (2003) reported experimental results that indicated that carbonate inhibited adsorption of U-VI onto ferrihydrite by forming uranyl carbonate complexes that exhibit a lower affinity to adsorb onto Fe hydroxide surfaces at intermediate $\mathrm{pH}$ values. The implication is that $U$ will exhibit a relatively high affinity for the aqueous phase in carbonate-rich waters. Virtually all $U$ in the SEWD shallow groundwater is predicted by PHREEQC to be complexed with carbonate groups, so consequently the HFO surface would not be expected to act as a reservoir for $U$ to the extent that it does for As, V, and Mo.

\section{Conclusions}

In summary, the multiple independent indicators measured as part of this study comprise an internally consistent picture of imported recharge water mixing with ambient groundwater in various proportions in the shallow aquifer underlying and surrounding the recharge ponds. Direct natural indicators of the imported recharge water - groundwater age, TDS, $\delta^{18} \mathrm{O}, \delta^{13} \mathrm{C}$ - as well as an introduced tracer all appear to be generally correlated in groundwater samples collected at the site, reflecting the varying extent of artificial recharge water present in the shallow aquifer. In addition, the introduction of the high quality (i.e., low-TDS), artificial recharge water, being out of equilibrium with the aquifer material, results in the mobilization of oxyanionic trace elements (As, V, and Mo) as well as changing the proportion of exchangeable cations in solution.

\section{Acknowledgments}

This work was performed under the auspices of the US Department of Energy by the University of California, Lawrence Livermore 
National Laboratory under Contract W-7405-ENG-48. Funding for this project was provided by the California State Water Resources Control Board Groundwater Ambient Monitoring and Assessment Program. The Groundwater Ambient Monitoring and Assessment program is sponsored by the State Water Resources Control Board and carried out in cooperation with the US Geological Survey. Philip Norton conducted field sampling and analysis. Rachel Lindvall and Roald Leif provided sample analysis. Kevin Kauffman and his staff at the Stockton East Water District granted access to the site and provided support for the sampling effort. We also wish to acknowledge the two peer reviewers for their constructive comments.

\section{References}

Aeschbach-Hertig, W., Peeters, F., Beyerle, U., Kipfer, R., 1999. Interpretation of dissolved atmospheric noble gases in natural waters. Water Resour. Res. 35, 2779-2792.

Appelo, C.A.J., Postma, D., 1993. Geochemistry, Groundwater and Pollution. A.A. Balkema, Rotterdam.

Arthur, J.D., Dabous, A.A., Cowart, J.B., 2002. Mobilization of arsenic and other trace elements during aquifer storage and recovery, southwest Florida. In: Aiken, G.R., Kuniansky, E.L. (Eds.), US Geological Survey Artificial Recharge Workshop Proc. Sacramento, California, April 2-4. US Geol. Surv. Open-File Rep. 02-89.

Belitz, K., Dubrovsky, N. M., Burow, K., Jurgens, B., Johnson, T., 2003. Framework for a Ground-Water Quality Monitoring and Assessment Program for California. US Geol. Surv. Water Resour. Invest. Rep. 03-4166.

Bouwer, H., 2002. Artificial recharge of groundwater: hydrogeology and engineering. Hydrogeol. J. 10, 121-142.

Burow, K.R., Shelton, J.L., Hevesi, J.A., Weissmann, G.S., 2004. Hydrogeologic Characterization of the Modesto Area, San Joaquin Valley, California. US Geol. Surv. Sci. Invest. Rep. 2004-5232.

Clark, J.F., Hudson, G.B., Davisson, M.L., Woodside, G., Herndon, R., 2004 Geochemical imaging of flow near an artificial recharge facility, Orange County, California. Ground Water 42, 167-174.

Dzombak, D.A., Morel, F.M.M., 1990. Surface Complexation Modeling - Hydrous Ferric Oxide. John Wiley \& Sons, New York.

Ekwurzel, B., 2004. LLNL Isotope Laboratories Data Manual, Version 12. Lawrence Livermore National Laboratory, UCRL-TM-203316.

Ekwurzel, B., Schlosser, P., Smethie, W.M., Plummer, L.N., Busenberg, E., Michel, R.L., Weppernig, R., Stute, M., 1994. Dating of shallow groundwater: comparison of the transient tracers $3 \mathrm{H} / 3 \mathrm{He}$, chlorofluorocarbons and $85 \mathrm{Kr}$. Water Resour. Res. $30,1693-1708$

Gaines, G.L., Thomas, H.C., 1953. Adsorption studies on clay minerals. 2. A formulation of the thermodynamics of exchange adsorption. J. Chem. Phys. $21,714-718$

Gamlin, J.D., Clark, J.F., Woodside, G., Herndon, R., 2001. Large-scale tracing of ground water with sulfur hexafluoride. J. Environ. Eng. - ASCE 127, 171-174.

Gao, S., Fujii, R., Chalmers, A.T., Tanji, K.K., 2004. Evaluation of adsorbed arsenic and potential contribution to shallow groundwater in Tulare Lake Bed area, Tulare Basin, California. Soil Sci. Soc. Am. J. 68, 89-95.

Gao, S., Goldberg, S., Herbel, M.J., Chalmers, A.T., Fujii, R., Tanji, K.K., 2006. Sorption processes affecting arsenic solubility in oxidized surface sediments from Tulare Lake Bed, California. Chem. Geol. 228, 33-43.
Green, J., 2008. Farmington Groundwater Recharge Program: Making Water a Crop for Eastern San Joaquin County's Future. Sacramento, California, USA.

Izbicki, J.A., 2008. Sources, distribution, and management of arsenic in water from wells, Eastern San Joaquin Ground-Water Subbasin, California, Personal communication.

Jones, J., 2003. Groundwater storage - the western experience. J. Am. Water Works Assoc. 95, 71-83.

Kortelainen, N.M., Karhu, J.A., 2006. Tracing the decomposition of dissolved organic carbon in artificial groundwater recharge using carbon isotope ratios. Appl. Geochem. 21, 547-562.

Manning, A.H., Thiros, S.A., 2005. H-3/He-3 age data in assessing the susceptibility of wells to contamination. Ground Water 43, 353-367.

Marchand, D.E., Allwardt, A., 1981. Late Cenozoic Stratigraphic Units, Northeastern San Joaquin Valley California. US Geol. Surv. Bull. 1470

Montgomery Watson Harza, 2006. Aquifer Test Work Plan., Farmington Groundwater Recharge Program, File 1511398.141802.

Moran, J.E., Hudson, G.B., Eaton, G.F., Leif, R., 2004. A contamination vulnerability assessment for the Santa Clara and San Mateo County Groundwater Basins. Lawrence Livermore National Laboratory, UCRL-TR-201929. <http:// www.waterboards.ca.gov/water_issues/programs/gama/gamadocs.shtml>

Parkhurst, D.L., Appelo, C.A.J., 2002. User's Guide to PHREEQC (Version 2) - A Computer Program for Speciation, Batch Reaction One-Dimensional Transport, and Inverse Geochemical Calculations. US Geol. Surv. Water-Resour. Invest. Rep. 99-4259.

Poreda, R.J., Cerling, T.E., Solomon, D.K., 1988. Tritium and helium-isotopes as hydrologic tracers in a shallow unconfined aquifer. J. Hydrol. 103, 1-9.

Pyle, S.T., 1988. Ground-water banking in Kern County, California. In: California Water-Use Data for Water Resource Management: Proc. Symp. American Water Resources Association, Bethesda, MD.

Quast, K.W., Lansey, K., Arnold, R., Bassett, R.L., Rincon, M., 2006. Boron isotopes as an artificial tracer. Ground Water 44, 453-466.

Rai, D., Zachara, J.M., 1984. Chemical Attenuation Rates, Coefficients, and Constants in Leachate Migration. A Critical Review, vol. I. Electric Power Research Institute, Palo Alto, CA (EA-3356).

Rose, T.P., Davisson, M.L., Criss, R.E., 1996. Isotope hydrology of voluminous cold springs in fractured rock from an active volcanic region, northeastern California. J. Hydrol. 179, 207-236.

Smedley, P.L., Kinniburgh, D.G., 2002. A review of the source, behaviour and distribution of arsenic in natural waters. Appl. Geochem. 17, 517-568.

Solomon, D.K., Poreda, R.J., Schiff, S.L., Cherry, J.A., 1992. Tritium and He-3 as groundwater age tracers in the Borden Aquifer. Water Resour. Res. 28, 741-755.

Sposito, G., 1989. The Chemistry of Soils. Oxford University Press, New York.

St-Jean, G., 2003. Automated quantitative and isotopic (C-13) analysis of dissolved inorganic carbon and dissolved organic carbon in continuous-flow using a total organic carbon analyser. Rapid Commun. Mass Spectrom. 17, 419-428.

Wazne, M., Korfiatis, G.P., Meng, X.G., 2003. Carbonate effects on hexavalent uranium adsorption by iron oxyhydroxide. Environ. Sci. Technol. 37, 36193624.

Weissmann, G.S., Zhang, Y., LaBolle, E.M., Fogg, G.E., 2002. Dispersion of groundwater age in an alluvial aquifer system. Water Resour. Res. 38 (article number 1198).

Welch, A.H., Westjohn, D.B., Helsel, D.R., Wanty, R.B., 2000. Arsenic in ground water of the United States: occurrence and geochemistry. Ground Water 38, 589-604.

Williams, L.E., Barnett, M.O., Kramer, T.A., Melville, J.G., 2003. Adsorption and transport of arsenic(V) in experimental subsurface systems. J. Environ. Qual. 32, 841-850.

Zhang, H., Selim, H.M., 2005. Kinetics of arsenate adsorption-desorption in soils. Environ. Sci. Technol. 39, 6101-6108. 